\section{Data and}

Information

as Property

Neville Holmes, University of Tasmania vices such as pictures, speech, and music-which have in the past been relatively awkward to deal with as analog data-have, through digital technology, become easy to produce and reproduce.

\section{INTELLECTUAL PROPERTY}

In the affluent fraction of the world at least, digital data has become more bureaucratically and commercially significant than any other product. In particular, its commercial significance has led to the rapid expansion and extension of so-called intellectual property (IP) law. The World Intellectual Prop-
D igital technologists concern themselves with data-conventional representations of facts or ideas-and with machines for storing, transforming, and transmitting it. Although computing professionals also concern themselves with digital technology, they focus primarily on people and information-the meaning that people give to data.

The use of data to convey information is vitally important to our social systems. This is underlined by recent research showing that dogs are much more able to get meaning from data than chimpanzees, which probably explains why dogs make better pets.

The sharing of meaning has been the foundation of social development. The different data technologies have been used both to empower and to constrain members of our society as technology and society have evolved together. Computing professionals should thus always be sensitive to the social uses of data and information. They should also be alert to legal developments related to using data and to digital technology's role in producing data.

\section{DATA'S EVOLUTION}

Spoken language was the first digital technology. Many oral societies were quite extensive and persistent, although oral data is short-lived and only persists through memory. The

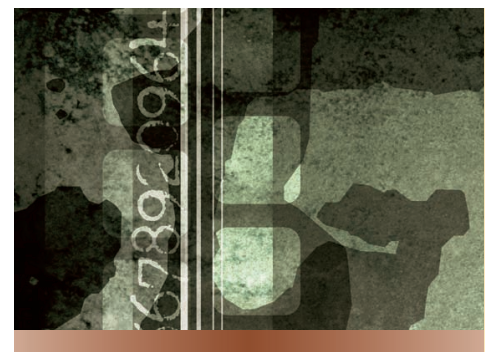

The legal and information aspects of data are of great concern to the profession.

rulers of successful oral societies depended on respect for oral tradition as reflecting acceptable past behavior.

Written language was the second digital technology. Writing gave a permanent and copyable aide memoire to the institutions in control of literate societies, making the written word law. Literacy remained the exclusive province of the elite until late in the development of printing.

Electromagnetic media underpins the third digital technology. Not only has the capture, storage, manipulation, transmission, and display of electromagnetic data gone far beyond that possible with the old kinds of written language that developed and developing societies use, it has also given the leaders of those societies much greater scope for controlling and exploiting the people under their leadership.

The use of digital technology now encompasses and facilitates not only written and spoken language, but also the production and delivery of goods and services. Abstract goods and ser- erty Organization (WIPO) and the international Trade Related Aspects of Intellectual Property Rights Agreement have extended such laws around the globe.

IP rights figure importantly, but remain almost unnoticed publicly, in so-called free-trade agreements such as the recently negotiated but not yet ratified agreement between Australia and the US.

The 1967 WIPO convention (www. wipo.int/clea/docs/en/wo/wo029en.htm) defines intellectual property to include those rights relating to:

- literary, artistic, and scientific works;

- performances of performing artists, phonograms, and broadcasts;

- inventions in all fields of human endeavor;

- scientific discoveries;

- industrial designs;

- trademarks, service marks, and Continued on page 90 
commercial names and designations; and

- protection against unfair competition.

WIPO's definition of IP also includes all other rights resulting from intellectual activity in the industrial, scientific, literary, or artistic fields.

Calling such rights intellectual property is a misnomer, and the definition is both a chimera and a hydra. The misnomer is because many of the rights do not result primarily from intellectual activity, especially when computers are used. The chimera is because it cobbles together quite different kinds of rights with quite independent and distinct histories. The hydra is because the definition's specific items go far beyond precedent, and a rapacious ambit claim follows them.

There are, or were, three kinds of property covered here: commercial identifications intended to provide for fair competition, novel ideas of use to industry, and original creations of interest to the public at large. Until recently, the first two kinds were usually called industrial property, for obvious reasons. Digital technology has great significance for all three kinds of property, which is why all computing professionals should take an active interest in IP law.

\section{Commercial identification}

The rights relating to industrial designs-and to trademarks, service marks, commercial names, and designations-are rights to produce goods with an appearance or with labeling or markings that identify the goods' origin.

Industrial design rights relate only to the visual appearance of goods. First introduced in England in 1787 in support of the textile industry, these rights provide a distinct industrial form of copyright. There has been much discussion of the overlap between appearance and function, but patents of invention rightly cover novel function. Provided this separation remains, using a computer to produce a design should not affect rights that a registration process ensuring distinctness of design establishes.

Trademark registration granted a monopoly that extended the protection of the tort of passing off, and it is nowadays supplemented legislatively by various trade practices, laws, and regulations intended to prevent unfair trading. However, the use of trademarks to

\section{Disputes over patents incur great expense and have notoriously unpredictable outcomes.}

identify the origin of goods is disappearing as they increasingly become the lynchpin of modern marketing, which uses them to condition purchasing behavior through advertising.

\section{Information as property}

The second kind of IP rights, monopoly in information, involves ideas as ideas, such as the rights established under patent law.

Nations began granting monopolies for inventions in Europe in the 15th century. England's Queen Elizabeth enthusiastically adopted the idea of such grants in the 16th century for a variety of monopolies, the official document of grant being called a letter patent.

Gross overuse of letters patents in England led to legislation in the 17th century that rendered all patent monopolies invalid except for patents that protected the "sole working or making of any manner of new manufacture." Governments granted these to inventors, a term which then included importers of technology.

The English tradition of patent law developed from this legislation. Several aspects of this tradition are important:

- Patents sought to encourage innovation for the good of the nation. An exception to the rule against monopolies, they were not primarily granted to reward the inventor, but to discourage the use of trade secrets that hamper innovation.

- Rights targeted innovation in manufacturing and excluded a "mere scheme or plan." The present extension into business processes and beyond is questionable.

- Novelty, a requirement, excludes any development that would be obvious to one skilled in the prior art. The plethora of patents being granted currently implies the scarcity of true novelty.

- Innovation excludes scientific discoveries. In the English tradition, such discoveries belong in the public domain-invention relates solely to the industrial exploitation of discoveries. Thus, while a new substance is not patentable, processes for making or exploiting that substance are.

Some indirect aspects are also important. For example, patent holders all too often use their rights to prevent innovation, which they do easily by blocking any innovation that extends their invention. Also, modern inventions typically have a much shorter useful life than a patent, denying the public any residual benefit.

Software patents are indefensible in principle ("The Evitability of Software Patents," Computer, Mar. 2000, pp. 30-34). Most importantly, disputes over patents incur great expense and have notoriously unpredictable outcomes. Patent holders can thus easily use litigation to discourage competition.

These aspects of the patent system are particularly relevant to computing professionals now that so many patents involve digital technology.

\section{Data as property}

The third kind of IP rights confers a monopoly in data-representations of facts or ideas, such as rights established under copyright law.

In England, the Stationers' Company established a monopoly in printing, and its members held exclusive control over 
the importation and publication of books. Because copyright holders came to use the monopoly extortionately, Parliament passed the Statute of Anne, an "Act for the Encouragement of Learning ...," in 1709. After an immense legal and political battle, it replaced the earlier and much wider monopoly. Originally covering books only, rights were gradually extended to artistic, dramatic, and musical works.

In general, copyright lets the owner control the copying of works, although extensions over the past few decades to cover modern works such as broadcasts and computer programs have made copyrights much more complicated. In essence, copyright pertains to the representation of a fact or idea, not the fact or idea itself. The work need not be novel, but it must be original, and until recently it had to be in material form.

The idea of copyright monopoly arose with the introduction of printing, but technology has made copyright grotesque (Simone Santini, "Bringing Copyright into the Information Age," Computer, Aug. 2003, pp. 104, 102-103). The first stage of the copyright farce came when photocopiers replaced spirit duplicators and Roneo machines, which led to absurd fee-collection systems. The farce continues today in the recorded music industry.

\section{THE FUTURE}

Digital technology has been universally adopted in the commercial world, so data is becoming the main and often only source of revenue for many enterprises. The importance of data to business enterprises has led to the extension of IP rights in scope, duration, and severity—and geographically through WIPO.

Extension of existing legislation and legislation for entirely new rights—such as those for circuit layouts and software patents-widens the scope of rights even further. The duration of both copyrights and patents of invention is being greatly extended. Large compa- nies, unable to protect their own intellectual property through the traditional civil courts, are persuading legislators to make crimes of what have always been torts, so that governments must enforce commercial property rights. Extended IP rights are being propagated internationally by, for example, so-called free trade agreements.

B ecause IP rights are of tremendous significance to computing professionals, we must be well informed about them. We have a clear duty to counter the persistently uttered falsehood that they are intended to reward the inventor or author who is, in fact, rarely the main beneficiary. Indeed, it seems likely that in the future, inventors and authors will often be computers.

Personal views on IP rights range widely. Identification rights are in principle necessary as a basis for fair trading in goods, but data and information have become goods in themselves. Given that capitalism is based on extending property rights to artificial entities, it would seem logical to extend the property rights themselves as far as capitalism requires. In contrast, since property rights are monopolies, and monopolies act in restraint of trade, free-market principles would outlaw copyright, patent, and related rights.

I believe that the expansion in scope and duration of these rights should be greatly and promptly reversed. Eliminating copyright and patents altogether would be interesting and certainly different, possibly more beneficial, but impractical.

As computing professionals, our views should be well founded, wherever in the spectrum they might lie. We should also be prompt to speak out against obvious absurdities, such as the push to bring deep linking under copyright law. If this push were to succeed, its logic would make it illegal for someone to cite this essay other than by giving its title, my name, and the name of this publication. Giving the date, volume and issue, and pages would be illegal and possibly criminal.

Neville Holmes is an honorary research associate at the University of Tasmania's School of Computing. Contact himatneville.holmes@utas.edu.au. Details of citations in this essay, and links to further material, are at www. comp.utas.edu.au/users/nholmes/prfsn.



